\title{
Costs of cannibalism in the presence of an iridovirus pathogen of Spodoptera frugiperda
}

\author{
TREVOR WILLIAMS ${ }^{1,2}$ and OLIVIA HER NÁ NDEZ ${ }^{1}{ }^{1}$ ECOSUR, Tapachula, Chiapas, \\ Mexico and ${ }^{2}$ Departamento de Producción Agraria, Universidad Pública de Navarra, Pamplona, Spain
}

\begin{abstract}
The costs of cannibalism were examined in larvae of Spodoptera frugiperda (J. E. Smith) (Lepidoptera: Noctuidae) in the presence of conspecifics infected by a lethal invertebrate iridescent virus (IIV). The hypothesis of a positive correlation between insect density and the likelihood of disease transmission by cannibalism was examined in laboratory microcosms and a field experiment.

2. Transmission was negligible following peroral infection of early instars with purified virus suspensions or following coprophagy of virus-contaminated faeces excreted by infected insects. In contrast, $92 \%$ of the insects that predated infected conspecifics acquired the infection and died prior to adult emergence in the laboratory. Diseased larvae were more likely to be victims of cannibalism than healthy larvae.

3. The prevalence of cannibalism was density dependent in laboratory microcosms with a low density ( 10 healthy insects + one infected insect) or high density (30 healthy insects + one infected insect) of insects, and field experiments performed on maize plants infested with one or four healthy insects + one infected insect.

4. Cannibalism in the presence of virus-infected conspecifics was highly costly to $S$. frugiperda; in all cases, insect survival was reduced by between $\approx 50 \%$ (laboratory) and $\approx 30 \%$ (field) in the presence of the pathogen. Contrary to expectations, the prevalence of disease was not sensitive to density because cannibalism resulted in self-thinning. As infected individuals are consumed and disappear from the population, the prevalence of disease will be determined by the timescale over which transmission can be achieved, and the rate at which individuals that have acquired an infection become themselves infectious to conspecific predators.
\end{abstract}

Key words. Cannibalism, coprophagy, density, iridovirus, pathogen transmission, Spodoptera frugiperda, survival.

\section{Introduction}

Certain species of Lepidoptera often engage in cannibalism during the larval stage of development (Pierce, 1995; Reed et al., 1996; Chapman et al., 1999b). Cannibalism may confer direct fitness benefits, in the form of increased

Correspondence: T. Williams, Departamento de Producción Agraria, Universidad Pública de Navarra, Pamplona 31006, Spain. E-mail: trevor.williams@unavarra.es survival, developmental rate, or fecundity (Duelli, 1981; Joyner \& Gould, 1985; Church \& Sherratt, 1996). Other benefits include the removal of potential competitors (Polis, 1981; Kakimoto et al., 2003), or a reduction in the probability of attracting predators (Chapman et al., 2000).

The benefits of cannibalism must be weighed up against three clear costs of intraspecific predation. First, cannibals risk death or injury from the defensive responses of conspecifics (Fox, 1975; Polis, 1981). Second, cannibalism may reduce inclusive fitness through the consumption of kin (Polis, 1981; Pfennig et al., 1993). Third, cannibalism may be costly if 
pathogens can be transmitted by feeding on infected conspecifics (Dhandapani et al., 1993; Vasconcelos, 1996; Boots, 1998, 2000; Pfennig et al., 1998; Chapman et al., 1999a).

Invertebrate iridescent viruses (IIVs) (Family: Iridoviridae, Genus: Iridovirus) are icosahedral particles, 120-140 nm diameter, containing a large DNA genome (Chinchar et al., 2005). An IIV has been isolated from larvae of the fall armyworm, Spodoptera frugiperda (J. E. Smith) (Lepidoptera: Noctuidae) in Argentina and Mexico (Vera et al., 1995; López et al., 2002). Patent IIV disease is obvious to the naked eye because larvae develop a characteristic iridescent blue hue due to the formation of crystalline arrays of virus particles in the epidermis, fat body and many other tissues of the infected insect. Patently infected insects can survive for extended periods (up to several weeks), but are usually unable to pupate and develop to the adult stage (Sikorowski \& Tyson, 1984). Patent infection is invariably lethal. Sublethal (covert) infections may also be common in IIV infections of some insects, notably Diptera and Ephemeroptera (Williams, 1993; Marina et al., 1999; Tonka \& Weiser, 2000), but laboratory studies have indicated that the IIV isolated from $S$. frugiperda does not usually cause covert infections in this species; virtually all infections are patent and lethal (O. Hernández, unpublished data).

The mechanisms of transmission of most IIVs are unclear. These viruses are not highly infectious by ingestion but are highly pathogenic by injection. Fall armyworm larvae are cannibalistic in the fifth and sixth instars (Chapman et al., 1999a). Cannibalism of infected conspecifics can present two potential routes for the transmission of the IIV: (i) wounds from defensive responses by the cannibal's victim and (ii) the consumption of massive doses of virus particles that may be sufficient to result in transmission. The likelihood of cannibalism is positively correlated with density in S. frugiperda larvae (Chapman et al., 1999a), and epidemiological models have highlighted the fundamental role of host density in the dynamics of pathogen transmission (Dieckmann, 2002; Swinton et al., 2002). Indeed, a recent study on IIV transmission in a mosquito has highlighted the importance of density-dependent aggressive interactions among conspecifics on the rate of virus transmission and the fraction of the host population that is susceptible to disease (Marina et al., 2005). Population density can also influence the ability of insects to combat invading pathogens. Lepidoptera that develop at high densities may can have altered susceptibility to infection by viruses (Goulson \& Cory, 1995; Reeson et al., 2000), and a marked increase in some functions of the immune system, compared with conspecifics reared at low density (Reeson et al., 1998; Wilson et al., 2001). However, these changes are accompanied by reductions in other aspects of immune function, indicating likely trade-offs in the immune system that constrain the insect from investing across the entire range of physiological responses to infection (Cotter et al., 2004a, b).

Risks of transmission by cannibalism in S. frugiperda are also dependent on stage, as only the later instars are highly cannibalistic (Chapman et al., 1999a). Stage dependency has been observed in the transmission of a granulovirus pathogen of the moth Plodia interpunctella, with the difference that the probability of cannibalistic transmission peaked in the middle (third and fourth) instars because the later instars become increasingly refractive to infection as they approach pupation (Boots, 1998).

In the present study, the hypothesis that the cannibalistic behaviour of S. frugiperda larvae would be costly in the presence of an IIV pathogen was examined. Specifically, the probability of infection following peroral consumption of very high doses of IIV at different stages of development, or the likelihood of transmission by coprophagy of the faeces from infected insects, was compared with the efficiency of transmission by cannibalism of infected conspecifics. Laboratory and field experiments were then performed to examine the hypothesis that increased insect density results in a higher prevalence of cannibalism that favours the transmission of the pathogen.

\section{Materials and methods}

\section{Insect colonies and virus stock}

A colony of $S$. frugiperda that originated from apparently healthy larvae collected from maize plants near Tapachula, Chiapas, Mexico was maintained at $24-27^{\circ} \mathrm{C}$, L:D $12 \mathrm{~h}: 12 \mathrm{~h}, \quad 75-90 \% \quad \mathrm{RH}$ on a semi-synthetic diet (adapted from Mihm, 1984). A colony of Galleria mellonella (L.) (Lepidoptera: Pyralidae) was maintained at $25 \pm 1{ }^{\circ} \mathrm{C}$ on a diet based on cereal + honey + glycerol (modified from Hunter \& Boraston, 1979). This insect is the standard laboratory host for IIV production and is highly sensitive to most IIVs; G. mellonella larvae develop patent signs of disease following injection of less than five particles of the IIV from S. frugiperda (N. Hernández \& T. Williams, unpublished data).

An IIV originally isolated from a patently infected S. frugiperda larva in southern Mexico (López et al., 2002) was grown by injecting a dilute virus suspension into fourth-instar $S$. frugiperda from the laboratory colony. These insects were reared on semi-synthetic diet and individuals that developed signs of patent infection were killed at 8 days post-injection and stored at $-20{ }^{\circ} \mathrm{C}$ until required. Virus was extracted and purified by trituration of infected larvae in sterile distilled water followed by centrifugation at 490,960 , and $1250 \mathrm{~g}$, each for $10 \mathrm{~min}$ to remove insect debris, followed by $15300 \mathrm{~g}$ for $10 \mathrm{~min}$ to pellet virus. The pellet was re-suspended in $300 \mu \mathrm{l}$ water, layered onto $35 \%$ (wt/vol.) sucrose and subjected to $15300 \mathrm{~g}$ for $30 \mathrm{~min}$. The resulting pellet was washed twice and re-suspended in $1 \mathrm{ml}$ sterile distilled water. The concentration of virus stock suspension was determined by direct observation of a mixture of virus particles and polystyrene beads $460 \mathrm{~nm}$ diameter (Aldrich Chemical Co., St. Louis, Missouri) dried onto polylysine coated glass coverslips, quantified using a scanning electron microscope (Constantino et al., 2001). Virus suspensions were stored at $4{ }^{\circ} \mathrm{C}$ and used within 7 days of purification. 


\section{Experiment 1: efficiency of peroral infection}

Groups of 30-50 third-instar S. frugiperda from the laboratory colony were starved for $4 \mathrm{~h}$ and then fed individually a suspension of IIV at one of the following doses $-1 \times 10^{7}, 2 \times 10^{8}$, or $4 \times 10^{8}$ particles using the contaminated diet plug method (Hunter-Fujita et al., 1998). Those larvae that consumed the diet plug within $12 \mathrm{~h}$ were transferred individually to plastic pots containing semi-synthetic diet, reared at $22{ }^{\circ} \mathrm{C}$ and checked daily for signs of patent IIV disease until pupation. Control larvae were treated with diet plugs treated with distilled water. The procedure was performed 10 times.

As the procedure with third instars did not result in many patent infections, the procedure was repeated with groups of 25 first instars $(<12 \mathrm{~h}$ old) using the droplet feeding method (Hunter-Fujita et al., 1998). For this, larvae were allowed to drink from a suspension containing $2 \times 10^{8}$ virus particles $\mu \mathrm{l}^{-1}$ mixed with $10 \%$ (wt/vol.) sucrose and $0.001 \%$ (wt $/$ vol.) blue food colouring. Larvae that drank the suspension in a 10 -min period were transferred individually to plastic pots with diet and checked daily for signs of patent IIV disease until pupation. Control larvae were treated with sucrose and food colouring solution alone. The procedure was performed four times.

\section{Experiment 2: virus in faeces}

Fourth-instar S. frugiperda were injected individually with $8.3 \mu \mathrm{l}$ of virus suspension estimated to contain an average of 3.0 IIV particles, placed in plastic pots with semi-synthetic diet, incubated at $22{ }^{\circ} \mathrm{C}$, and checked daily for signs of patent disease. The procedure was repeated with a group of 16 healthy fourth-instar larvae that were injected with water alone. At 6 days post-injection, nine of the 40 insects injected had not developed signs of disease and were discarded. The remaining 31 infected insects and 16 control insects were suspended individually from the lids of sterile empty plastic pots using cotton thread tied just below the head capsule. After $8 \mathrm{~h}$, the faeces of these insects were collected (39 mg per insect wet wt; $12.9 \mathrm{mg}$ per insect dry wt), homogenised in $1 \mathrm{ml}$ of $0.01 \%$ (wt/vol.) aureomycin solution, and subjected to centrifugation $(525 \mathrm{~g}$ for $5 \mathrm{~min}$ followed by $960 \mathrm{~g}$ for $10 \mathrm{~min}$ ) to sediment debris and bacteria. Volumes of $8.3 \mu \mathrm{l}$ of the supernatant were injected into groups of 10 third-instar G. mellonella. The injected larvae were incubated at $25 \pm 1{ }^{\circ} \mathrm{C}$ in plastic pots containing diet and checked for signs of patent disease at 10-12 days post-injection.

\section{Experiment 3: transmission by cannibalism in laboratory}

A single patently infected fifth-instar S. frugiperda (6 days post-infection) was placed in a plastic Petri dish containing two healthy conspecifics of the same instar and a piece of semi-synthetic diet $(30 \times 5 \times 5 \mathrm{~mm})$, which represented an excess for the period of the experiment. Petri dishes were incubated at $22{ }^{\circ} \mathrm{C}$ for $48 \mathrm{~h}$ and then the number of surviving larvae was noted. Healthy survivors were transferred individually to plastic pots containing diet, reared to pupation, and checked daily for signs of patent disease. The experiment was performed 78 times. The experiment was repeated with three healthy larvae (no infected larvae) on 48 occasions.

\section{Experiment 4: survival in microcosms in the presence of infected insects}

Groups of 30 fourth-instar larvae were placed in ventilated plastic boxes $(22 \times 14 \times 7.5 \mathrm{~cm}$; length $\times$ width $\times$ height) containing two $6-\mathrm{cm}$ diameter Petri dish lids in each of which were placed $30-\mathrm{g}$ blocks of semi-synthetic diet. A piece of clean paper $(11 \times 14 \mathrm{~cm})$ was folded in a concertina pattern and placed between the diet blocks to provide a surface for moulting. Finally, a fourth-instar larva was added to each box; this larva had been infected by injection of virus 6 days prior to the experiment and showed the typical symptoms of patent IIV infection. Control boxes received an additional healthy larva. Boxes were held at $25 \pm 1{ }^{\circ} \mathrm{C}$, L:D $12 \mathrm{~h}: 12 \mathrm{~h}$ photoperiod and the number of surviving larvae was recorded at 2-day intervals. Diet was replaced when the diet volume appeared to be half that present at the start of the experiment. When larvae pupated, pupae were removed from the boxes and placed in paper-lined Petri dishes to check for adult emergence. The experiment was performed 15 times for controls and virus treatments alike. An identical experiment was performed using groups of 10 larvae per box with an additional healthy or infected larva for control and virus treatments respectively.

\section{Experiment 5: transmission by cannibalism in the field}

A field experiment was performed in a $\approx 0.4$-ha field of maize (local creole variety) planted near the village of Alvaro Obregón, Chiapas. Plants of $70 \mathrm{~cm}$ height, with no signs of infestation by $S$. frugiperda, were selected at points scattered throughout the field. All experimental plants $(n=80)$ were sprayed with cypermethrin at approxi-

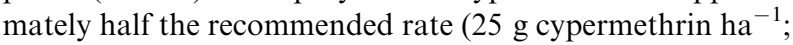
FMC Arrivo 25 EC), which previous studies indicated was sufficient to eliminate virtually all predatory insects from maize plants. This step was taken to avoid interference in the survival of experimental $S$. frugiperda larvae. At $1 \mathrm{~h}$ after spraying, the upper half of each plant was covered with a nylon gauze bag ( $20 \mathrm{~cm}$ wide $\times 35 \mathrm{~cm}$ long), which was tied at the base to prevent entry of insect predators. Five days later, plants were assigned randomly to one of four treatments: (i) two healthy larvae, (ii) five healthy larvae, (iii) one healthy + one infected larva, (iv) four healthy + one infected larva. In all cases, larvae were late fourth instars. After larvae were placed on the plants, the 
gauze bag was replaced and tied at the base. After $48 \mathrm{~h}$, the plants were cut and transported immediately to the laboratory where the bag was removed and plants were dissected individually. Living larvae were transferred individually to plastic pots containing semi-synthetic diet, reared in a laboratory incubator at $22 \pm 1{ }^{\circ} \mathrm{C}$ and checked daily for signs of patent IV infection. In case of doubt, larvae were homogenised individually in $1 \mathrm{ml}$ of water and the homogenate centrifuged to detect the presence of an iridescent blue pellet.

\section{Statistical analyses}

The frequencies of surviving insects in the Petri dish experiments, healthy and infected insects recovered from maize plants, insects that acquired infection in virus treatments, and the emergence of pupae from the microcosm experiment were examined by $\chi^{2}$ tests. The mean proportions of larvae that survived from control and virus treatments in the field and of the insects that survived to pupate in laboratory microcosms were subjected to generalised linear modelling with model simplification in GLIM (Numerical Algorithms Group, 1993) with a binomial error structure specified. The appropriateness of these analyses was examined using the model-checking macro present in the GLIM program. Minor overdispersion was taken into account by scaling when necessary. F-tests were then performed to determine the significance of changes in model deviance (Crawley, 1993).

\section{Results}

\section{Experiment 1: efficiency of peroral infection}

Very few of the larvae inoculated in the third instar developed IIV disease. The prevalence of infection did not exceed $5.6 \%$ at any dose (1/378 larvae inoculated with $1 \times 10^{7}$ particles, $21 / 378$ larvae inoculated with $2 \times 10^{8}$ particles, and $16 / 378$ larvae inoculated with $4 \times 10^{8}$ particles). Similarly, when inoculated with a high concentration of IIV in the first instar, only 3/100 larvae developed patent disease. Control larvae never developed virus infections following mock inoculation in either instar.

\section{Experiment 2: virus in faeces}

None of the G. mellonella larvae injected with faeces from control $S$. frugiperda developed signs of IIV disease. Of the 31 faecal samples obtained from infected $S$. frugiperda larvae, 30 resulted in patent disease when injected into $G$. mellonella larvae. Of those 30 samples, the mean prevalence of infection of G. mellonella larvae was $89.0 \%$ (range of SE 85.3-91.8). As the 90\% infective dose of this virus in $G$. mellonella is less than 10 particles per larva (N. Hernandez, unpublished data), and each
G. mellonella was inoculated with $8.3 \mu \mathrm{l}$ from a total suspension of $1 \mathrm{ml}$, this means that each faeces suspension contained an average of $<1205$ IIV particles (equivalent to 30 particles per mg faeces wet wt, or 93 particles per $\mathrm{mg}$ dry wt), which is orders of magnitude lower than the concentrations used to inoculate neonate and third-instar $S$. frugiperda in experiment 1 . It is concluded here that transmission by coprophagy is highly unlikely.

\section{Experiment 3: transmission by cannibalism in laboratory}

Survival of infected larvae for $48 \mathrm{~h}$ (17/78 insects) in Petri dishes was significantly reduced compared with that of healthy conspecifics $\left(105 / 156\right.$ insects; $\chi^{2}{ }_{1}=43.2$, $P<0.001)$. Larvae that had consumed an infected individual produced iridescent faeces indicating that massive quantities of virus had been consumed. Of the 105 healthy survivors, 97 subsequently developed patent IIV disease when incubated individually in the laboratory $(92 \%$ transmission). In the controls consisting of three healthy larvae per dish, 77/144 larvae survived the 48-h incubation period. None of these insects developed patent disease during subsequent individual rearing.

\section{Experiment 4: survival in microcosms in the presence of infected insects}

Survival during the larval stage was not affected by the presence of the virus at either density (Fig. 1a,b), although it was evident that transmission was occurring due to the disappearance of the initial infected individual and the subsequent appearance of patently infected larvae. However, this was not a common observation and infected individuals usually disappeared from one census to the next. Survival to the pupal stage was significantly reduced at high density compared with the low density treatment $\left(F_{1,59}=10.91, P<0.002\right.$, scale parameter $\left.=2.16\right)$, presumably due to an increased prevalence of cannibalism at the high density. The presence of virus resulted in a marked reduction in the proportion of insects that pupated successfully at both densities $\left(F_{1,58}=7.06, P=0.010\right.$, scale parameter $=2.16$ ). Of the initial cohort, $20.4 \%$ (range of SE: 17.8-23.3) pupated successfully in the high density control against $9.5 \%$ (SE: 7.7-11.6) in the high density virus treatment. Similarly, 42.4\% (SE: 36.9-48.2) pupated successfully in the low density control against $25.4 \%$ (SE: 20.8-30.7) in the low density virus treatment. Many of the virus-infected insects died during the pupation process with clear deformations and inability to slough the larval epidermis. There was no significant interaction between density and virus treatment $\left(F_{1,57}=0.04, P>0.05\right.$, scale parameter $=2.16$ ). Virus treatment also resulted in a significantly reduced emergence of adults from pupae at both densities (Table 1). Homogenisation and centrifugation of pupae that failed to emerge revealed that most had died of IIV disease. 


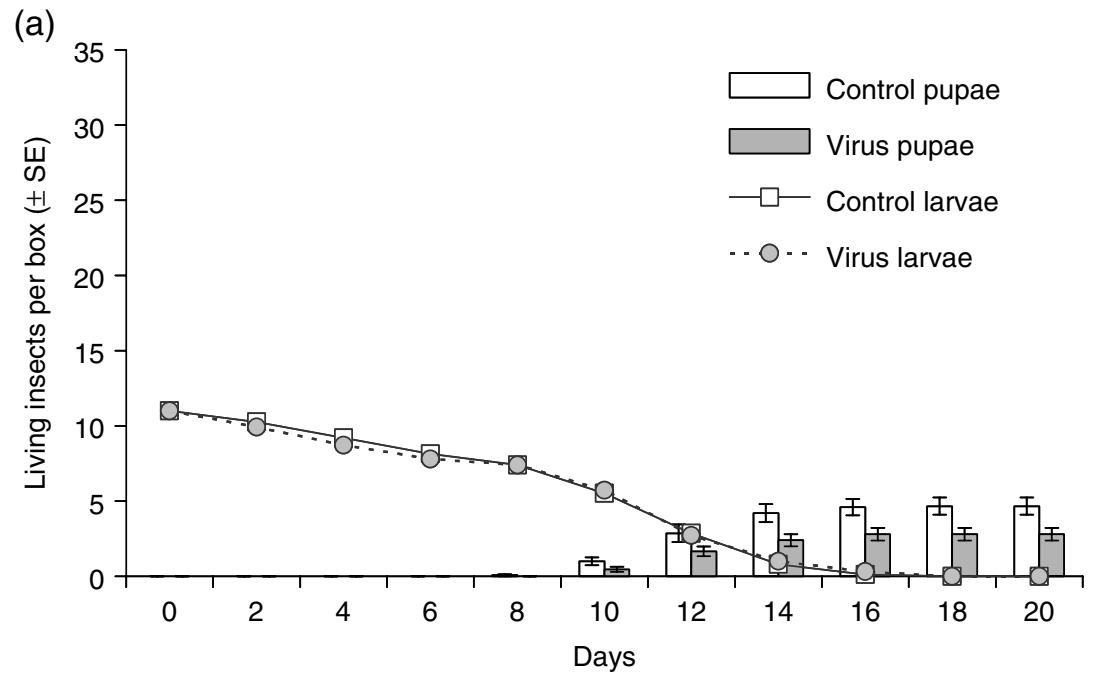

(b)

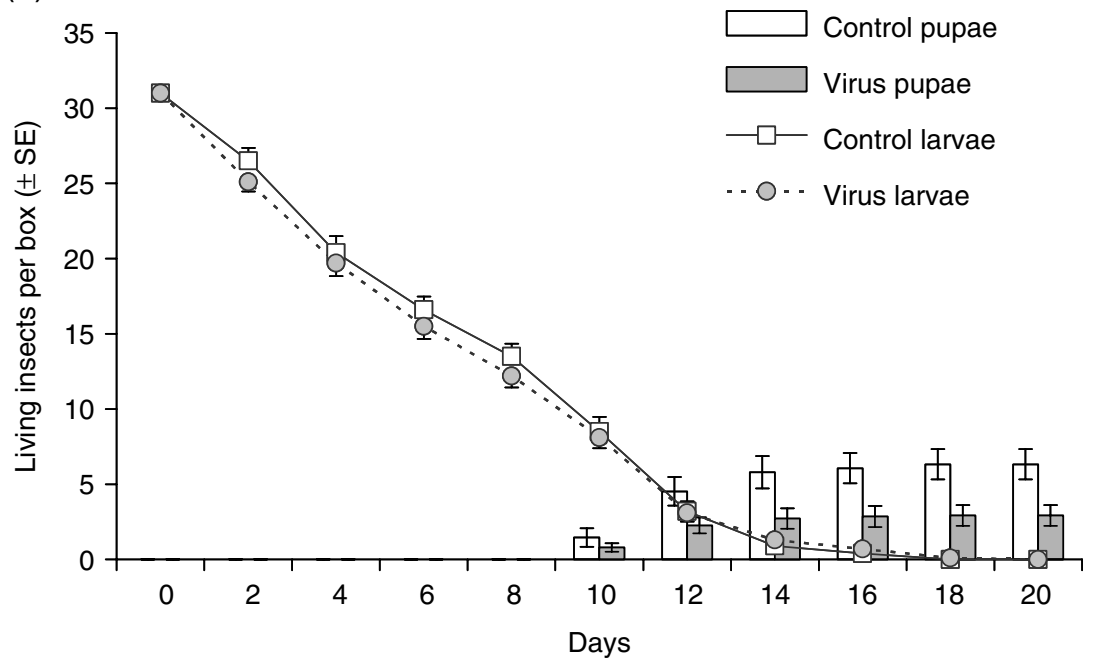

Fig. 1. Survival of Spodoptera frugiperda larvae (lines) and recovery of pupae (bars) in laboratory microcosms involving a healthy larva (control treatment), or single virus-infected larva (virus treatment), and (a) 10 (low density) or (b) 30 (high density) healthy insects co-inhabiting microcosms with abundant food supply.
Experiment 5: transmission by cannibalism in the field

The high survival of control larvae at low density indicated that insecticide residues applied to eliminate natural enemies on maize plants had been sufficiently degraded or diluted so as not to affect the responses of experimental insects. The mean proportion of larvae that survived the $48 \mathrm{~h}$ experimental period was significantly reduced at the highest density $\left(\chi^{2}{ }_{1}=12.9, P<0.001\right)$, and was lower in the treatment involving infected larvae compared with controls $\left(\chi_{1}^{2}=4.36, P=0.036\right)$ (Fig. 2$)$. Considering the survival of insects in the virus treatment alone, infected larvae disappeared (due to presumed cannibalism) more frequently than healthy larvae at low density but disappeared at the same rate as healthy larvae at high density (Table 2).

Density did not affect the probability of acquiring infection in the virus treatment: $27.8 \%$ (SE: 18.5-39.4) of healthy insects from the low density subsequently developed patent disease when incubated in the laboratory, compared with $36.4 \%$ (SE: 28.5-45.1) of insects that developed disease from the high density treatment $\left(\chi^{2}{ }_{1}=0.39\right.$, $P=0.53)$. None of the insects recovered from the control treatment developed IIV disease in the laboratory.

Table 1. Prevalence of emergence of Spodoptera frugiperda adults from pupae from control and virus treatments involving a healthy control, or single virus-infected insect, and 10 (low density) or 30 (high density) healthy insects co-inhabiting microcosms with abundant food supply in the laboratory. Percentage values shown in parentheses.

\begin{tabular}{lllll}
\hline & \multicolumn{2}{l}{ Emergence of pupae (\%) } & & \\
\cline { 2 - 3 } Treatment & Control & Virus & $\chi^{2}{ }_{1}$ & $P$ \\
\hline Low density & $53 / 69(77)$ & $19 / 42(45)$ & 11.4 & $<0.001$ \\
High density & $83 / 93(89)$ & $23 / 44(52)$ & 23.1 & $<0.001$ \\
\hline
\end{tabular}




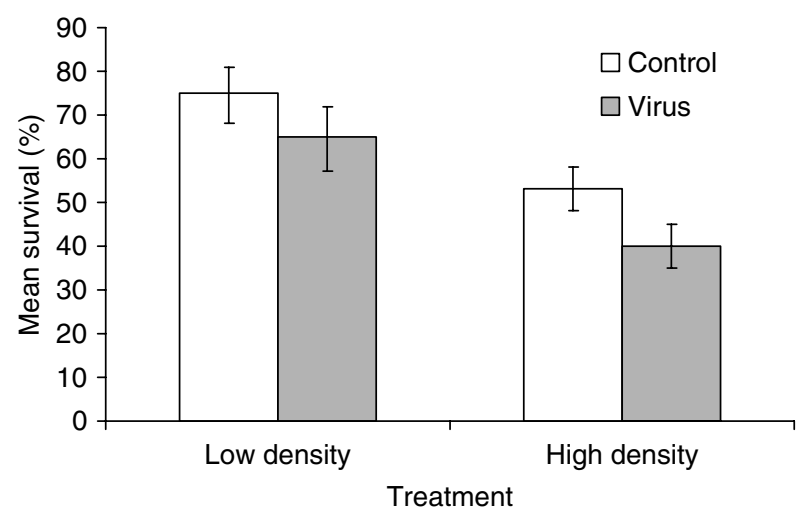

Fig. 2. Survival of Spodoptera frugiperda larvae in field trial involving a healthy larva (control treatment) or a virus-infected insect (virus treatment) and one (low density) or four (high density) healthy insects co-inhabiting the leaf whorl of maize plants for a 48-h period. Bars indicate SE and are asymmetrical.

\section{Discussion}

Very few S. frugiperda larvae, either first or third instars, developed IIV disease following ingestion of virus suspensions, despite the use of highly concentrated inoculum. This is in line with previous observations on the low peroral infectivity of these viruses (Williams, 1998). This indicates that acquisition of infection by feeding on contaminated foliage, the principal route of infection for most insect DNA viruses, is probably negligible for transmission of IIV in S. frugiperda.

Fall armyworm larvae produce abundant faeces localised in the leaf whorl of the maize plant. This led us to examine the risks of pathogen transmission by coprophagy. The presence of a low concentration of virus particles detected in the faeces collected from infected larvae indicates that the risks posed by coprophagy are negligible, although transmission could occur during moulting or entry through wounds in the presence of contaminated faeces. Similar results have been reported in infected Tipula spp., which excreted IIV particles but in insufficient quantities to cause peroral infection (Carter, 1973). Conversely, nucleopolyhedroviruses are highly infectious by ingestion and virus present in the faeces of infected Lepidoptera can result in transmission to healthy larvae (Ali et al., 1987; Vasconcelos, 1996).

In contrast, cannibalism was shown to be a very costly practice when infected individuals were present, for two

Table 2. Prevalence of $48 \mathrm{~h}$ survival in Spodoptera frugiperda larvae from virus treatment of field trial involving a single infected insect and one (low density) or four (high density) healthy insects co-inhabiting the leaf whorl of maize plants. Percentage values shown in parentheses.

\begin{tabular}{llllll}
\hline \multirow{2}{*}{ Treatment } & \multicolumn{2}{l}{ Survival (\%) } & & \multicolumn{2}{l}{} \\
\cline { 2 - 3 } & Healthy & Infected & & $\chi^{2}{ }_{1}$ & $P$ \\
\hline Low density & $18 / 20(90)$ & $8 / 20(40)$ & 10.9 & $<0.001$ \\
High density & $33 / 80(41)$ & $7 / 20(35)$ & 0.26 & $0.61(\mathrm{NS})$ \\
\hline
\end{tabular}

reasons. First, infected insects were far more likely to be victims of cannibalism, probably due to their sluggish responses and poor defensive reactions (Poprawski \& Yule, 1990; López et al., 2002) that probably arise from major changes in the metabolic activity of infected insects (Thompson \& Sikorowski, 1981). Second, in the laboratory, a very high proportion of cannibals $(92 \%)$ that had consumed infected conspecifics subsequently developed IIV disease, from which they died prior to reaching the adult stage. This was probably due to a combination of entry of virus via wounds inflicted while devouring the victim, and more particularly, the consumption of massive quantities of virus. Infected fifth instar $S$. frugiperda of mean weight $35.1 \pm 1.1 \mathrm{mg}$ contained approximately $5 \times 10^{10}$ particles of IIV (T. Williams, unpublished data), far more than present in the concentrated inoculum used for the peroral infection experiments. Indeed, IIVs are the most productive viruses known; approximately $25 \%$ of the body weight of an infected insect comprises virus particles (Williams \& Smith, 1957).

Cannibalism was density dependent in microcosm experiments, but the effect of the pathogen on insect survival was not evident until the insects began to pupate. The virus reduced the number of pupae by about $50 \%$ at both densities, and of those insects that did manage to pupate, only about $50 \%$ emerged as adults in the virus treatments compared with $77-89 \%$ in the control treatments. Infected insects suffered deformations, rupture of the tegument, and failure to slough the larval epidermis; all characteristic of IIV pathology during pupation (Smith et al., 1961; Carter, 1974). The overall production of adults from virus boxes (19 and 23 from low and high density treatments respectively) was very much reduced compared with that of control boxes (53 and 83 adults respectively), confirming that cannibalism was costly to insect survival in the presence of the pathogen. Cannibalism resulted in self-thinning of the insect population at both densities, so that the number of insects that pupated per box was similar for high and low density treatments (two or three pupae per box in virus treatments; five or six pupae per box in control treatments).

Cannibalism and virus transmission were also observed in the field experiment. Compared with controls consisting entirely of healthy larvae, a higher incidence of disappearance of larvae occurred in the treatments in which one larva was infected. The survival of those infected larvae was significantly reduced at the low density, indicating that they had been cannibalised, whereas at high density, the probability of survival of infected larvae was the same as the healthy conspecifics inhabiting the same leaf whorl. This observation has been interpreted here as evidence that high density larvae were indiscriminate in their elimination of cohabiting larvae, attacking infected individuals to the same degree as healthy larvae. However, at low density, in the absence of alternative potential victims, the single infected larva suffered a high probability of succumbing to conspecific predation. As a result, transmission of the pathogen was not sensitive to the density of healthy larvae, with about one-third of larvae developing IIV disease at both densities. 
Contrary to our hypothesis, the rate of cannibalism was density dependent in laboratory and field experiments, but in neither case did density affect the prevalence of virus disease. The principal reason underlying the differences in survival in laboratory microcosms and field observations lies in the different periods during which larvae interacted in each experiment. Larvae in microcosms experienced selfthinning over a 10-16-day period and reached a final density that depended on the presence or absence of the pathogen more than the original starting density. During this time, several cycles of transmission occurred as patently infected larvae were observed at intervals during the experiment, but rarely survived until the next sampling time; infected individuals fell victim to cannibals and therefore disappeared from the population. However, the magnitude of cannibal-mediated transmission only became apparent when infected insects died while attempting to pupate or prior to adult emergence (Fig. 1a,b). In contrast, the brief period (48 h) during which larvae came into contact with conspecifics in the field was not sufficient for the selfthinning process to reach its conclusion, that usually results in just one larva surviving on each maize plant (Labette, 1993), and only a single cycle of transmission was possible.

Pathogen transmission by predation becomes increasingly risky as the phylogenetic similarity between predator and prey increases, the greatest risk therefore being posed by conspecific predation (Pfennig, 2000). However, the risk of acquiring a lethal disease is not the only cost to cannibalism in $S$. frugiperda. Cannibals can suffer reduced survival, lower pupal weights, and reduced development rates depending on food availability (Chapman et al., 1999b). Cannibalism was only advantageous when food was limiting, whereupon predation of conspecifics can result in fitness benefits in increased development rate, a phenomenon common to other noctuids (Kakimoto et al., 2003) and other insect orders (Church \& Sherratt, 1996; De Block \& Stoks, 2004; Spänhoff et al., 2005). However, this behaviour may be adaptive when viewed as a strategy for reduced attraction of predators to high density patches of prey (Chapman et al., 2000) or for minimising the release of volatile plant compounds that attract endoparasitic wasps (Turlings et al., 1995; Bernasconi Ockroy et al., 2001). IIVinfected larvae are more prone to being stung than their healthy conspecifics due to their sluggish defence responses and endoparasitoid wasps can transmit IIV infection efficiently during the process of inserting the ovipositor contaminated with virus particles acquired after having stung an infected host (López et al., 2002).

In conclusion, cannibalism is a highly efficient mechanism for the transmission of an iridovirus pathogen. The rate of cannibalism was density dependent in field and laboratory studies. In all cases, insect survival was reduced in the presence of the pathogen. Cannibalism resulted in self-thinning and was preferentially directed at diseased insects. In such circumstances, the prevalence of disease will be determined by the timescale over which transmission can be achieved and the rate at which individuals that have acquired an infection become themselves infectious to conspecific predators.

\section{Acknowledgements}

We thank Juan Cisneros, Dora I. Penagos, Gerardo Hernández, Noe Hernández, and Guadalupe Nieto for technical assistance. The study received financial support from CONACyT 32024B.

\section{References}

Ali, M.I., Young, S.Y. \& Yearian, W.C. (1987) Nuclear polyhedrosis transmission by infected Heliothis zea (Boddie) (Lepidoptera: Noctuidae) prior to death. Journal of Entomological Science, 22 , 289-294.

Bernasconi Ockroy, M.L., Turlings, T.C.J., Edwards, P.J., Fritzsche-Hoballah, M.E., Ambrosetti, L., Bassetti, P. et al. (2001) Response of natural populations of predators and parasitoids to artificially induced volatile emissions in maize plants (Zea mays L.). Agricultural and Forest Entomology, 3, 201-210.

Boots, M. (1998) Cannibalism and the stage-dependent transmission of a viral pathogen of the Indian meal moth, Plodia interpunctella. Ecological Entomology, 23, 118-122.

Boots, M. (2000) Density-independent resource limitation and the transmission of an insect pathogen. Oecologia, 124, 172-175.

Carter, J.B. (1973) The mode of transmission of Tipula iridescent virus. I. Source of infection. Journal of Invertebrate Pathology, 21, 123-130.

Carter, J.B. (1974) Tipula iridescent virus infection in the developmental stages of Tipula oleracea. Journal of Invertebrate Pathology, 24, 271-281.

Chapman, J.W., Williams, T., Escribano, A., Caballero, P., Cave, R.D. \& Goulson, D. (1999a) Age-related cannibalism and horizontal transmission of a nuclear polyhedrosis virus in larval Spodoptera frugiperda. Ecological Entomology, 24, 268-275.

Chapman, J.W., Williams, T., Escribano, A., Caballero, P., Cave, R.D. \& Goulson, D. (1999b) Fitness consequences of cannibalism in the fall armyworm, Spodoptera frugiperda. Behavioral Ecology, 10, 298-303.

Chapman, J.W., Williams, T., Martínez, A.M., Cisneros, J., Caballero, P., Cave, R.D. et al. (2000) Does cannibalism in Spodoptera frugiperda reduce the risk of predation? Behavioural Ecology and Sociobiology, 48, 321-327.

Chinchar, V.G., Essbauer, S., He, J.G., Hyatt, A., Miyazaki, T., Seligy, V. et al. (2005) Iridoviridae. Virus Taxonomy: Eighth Report of the International Committee on the Taxonomy of Viruses (ed. by C. M. Fauquet, M. A. Mayo, J. Maniloff, U. Desselberger and L. A. Ball), pp. 163-175. Elsevier, London.

Church, S.C. \& Sherratt, T.N. (1996) The selective advantages of cannibalism in a Neotropical mosquito. Behavioural Ecology and Sociobiology, 39, 117-123.

Constantino, M., Christian, P., Marina, C.F. \& Williams, T. (2001) A comparison of techniques for detecting Invertebrate iridescent virus 6. Journal of Virological Methods, 98, 109-118.

Cotter, S.C., Hails, R.S., Cory, J.S. \& Wilson, K. (2004a) Densitydependent prophylaxis and condition-dependent immune function in Lepidopteran larvae: a multivariate approach. Journal of Animal Ecology, 73, 283-293.

Cotter, S.C., Kruuk, L.E.B. \& Wilson, K. (2004b) Costs of resistance: genetic correlations and potential trade-offs in an insect immune system. Journal of Evolutionary Biology, 17, 421-429.

Crawley, M.J. (1993) GLIM for Ecologists. Blackwell, Oxford.

De Block, M. \& Stoks, R. (2004) Cannibalism-mediated life history plasticity to combined time and food stress. Oikos, 106, 587-597. 
Dhandapani, N., Jayaraj, S. \& Rabindra, R.J. (1993) Cannibalism on nuclear polyhedrosis-virus infected larvae by Heliothis armigera (Hubn.) and its effect on viral-infection. Insect Science and Applications, 14, 427-430.

Dieckmann, U. (2002) Adaptive dynamics of pathogen-host interactions. Adaptive Dynamics of Infectious Diseases: In Pursuit of Virulence Management (ed. by U. Dieckmann, J. A. J. Metz, M. W. Sabelis and K. Sigmund), pp. 39-59. Cambridge University Press, Cambridge.

Duelli, P. (1981) Is larval cannibalism in lacewings adaptive? (Neuroptera: Chrysopidae). Research in Population Ecology, 23, 193-209.

Fox, L.R. (1975) Cannibalism in natural populations. Annual Review of Ecology and Systematics, 6, 87-106.

Goulson, D. \& Cory, J.S. (1995) Responses of Mamestra brassicae (Lepidoptera: Noctuidae) to crowding: interactions with disease resistance, colour phase and growth. Oecologia, 104, 416-423.

Hunter, F.R. \& Boraston, R.C. (1979) Application of the laurel immunoelectrophoresis technique to the study of serological relationships between granulosis viruses. Journal of Invertebrate Pathology, 34, 248-256.

Hunter-Fujita, F.R., Entwistle, P.F., Evans, H.F. \& Crook, N.E. (1998) Insect Viruses and Pest Management. John Wiley, Chichester.

Joyner, K. \& Gould, F. (1985) Developmental consequences of cannibalism in Heliothis zea (Lepidoptera, Noctuidae). Annals of the Entomological Society of America, 78, 24-28.

Kakimoto, T., Fujisaki, K. \& Miyatake, T. (2003) Egg laying preference, larval dispersion and cannibalism in Helicoverpa armigera (Lepidoptera: Noctuidae). Annals of the Entomological Society of America, 96, 793-798.

Labette, J.M. (1993) Within-plant distribution of fall armyworm (Lepidoptera: Noctuidae) larvae on corn during whorl-stage infestation. Florida Entomologist, 76, 437-447.

López, M., Rojas, J.C., Vandame, R. \& Williams, T. (2002) Parasitoid-mediated transmission of an iridescent virus. Journal of Invertebrate Pathology, 80, 160-170.

Marina, C.F., Arredondo-Jiménez, J.I., Castillo, A. \& Williams, T. (1999) Sublethal effects of iridovirus disease in a mosquito. Oecologia, 119, 383-388.

Marina, C.F., Fernández-Salas, I., Ibarra, J.E., Arredondo-Jiménez, J.I., Valle, J. \& Williams, T. (2005) Transmission dynamics of an iridescent virus in an experimental mosquito population: the role of host density. Ecological Entomology, 30, 376-382.

Mihm, J.A. (1984) Técnicas Eficientes para la Crianza Masiva e Infestación de Insectos, en la Selection de las Plantas Hospedantes para Resistencia al Gusano Cogollero, Spodoptera frugiperda. Centro Internacional de Mejoramiento de Maíz y Trigo (CIMMYT), El Batán, Mexico.

Numerical Algorithms Group (1993) The GLIM System: Release 4 Manual (ed. by B. Francis, M. Green and C. Payne). Oxford University Press, Oxford.

Pfennig, D.W. (2000) Effect of predatory-prey phylogenetic similarity on the fitness consequences of predation: a tradeoff between nutrition and disease. American Naturalist, 155, 335-345.

Pfennig, D.W., Ho, S.G. \& Hoffman, E.A. (1998) Pathogen transmission as a selective force against cannibalism. Animal Behavior, 55, 1255-1261.

Pfennig, D.W., Reeve, H.K. \& Sherman, P.W. (1993) Kin recognition and cannibalism in spadefoot toad tadpoles. Animal Behaviour, 46, 87-94.

Pierce, N.E. (1995) Predatory and parasitic Lepidoptera: carnivores living on plants. Journal of the Lepidopterists Society, 49, 412-453.
Polis, G.A. (1981) The evolution and dynamics of intraspecific predation. Annual Review of Ecology and Systematics, 12, 225-251.

Poprawski, T.J. \& Yule, W.N. (1990) A new small iridescent virus from grubs of Phyllophaga anxia (LeConte) (Col. Scarabidae). Journal of Applied Entomology, 110, 63-67.

Reed, D.J., Begon, M. \& Thompson, D.J. (1996) Differential cannibalism and population-dynamics in a host-parasitoid system. Oecologia, 105, 189-193.

Reeson, A.F., Wilson, K., Gunn, A., Hails, R.S. \& Goulson, D. (1998) Baculovirus resistance in the noctuid Spodoptera exempta is phenotypically plastic and responds to population density. Proceedings of the Royal Society of London. Series B, 265, 1787-1791.

Reeson, A.F., Wilson, K., Cory, J.S., Hankard, P., Weeks, J.M., Goulson, D. et al. (2000) Effects of phenotypic plasticity on pathogen transmission in the field in a Lepidoptera-NPV system. Oecologia, 124, 373-380.

Sikorowski, P.P. \& Tyson, G.E. (1984) Per os transmission of iridescent virus of Heliothis zea (Lepidoptera: Noctuidae). Journal of Invertebrate Pathology, 44, 97-102.

Smith, K.M., Hills, G.J. \& Rivers, C.F. (1961) Studies on the crossinoculation of the Tipula iridescent virus. Virology, 13, 233-241.

Spänhoff, B., Kock, C., Meyer, A. \& Meyer, E.I. (2005) The effect of food supply and larval cannibalism on adult size and biomass of the grazing caddis-fly Melampophylax mucoreus (Limnephilidae). Ecological Entomology, 30, 138-145.

Swinton, J., Woolhouse, M.E.J., Begon, M.E., Dobson, A.P., Ferroglio, E., Grenfell, B.T. et al. (2002) Microparasite transmission and persistence. The Ecology of Wildlife Diseases (ed. by P. J. Hudson, A. Rizzoli, B. T. Grenfell, H. Heesterbeek and A. P. Dobson), pp. 83-101. Oxford University Press, Oxford.

Thompson, A.C. \& Sikorowski, P.P. (1981) Energy difference in lipid and glycogen metabolism of healthy and iridescent virus infected Heliothis zea (Boddie). Comparative Biochemistry and Physiology, 70B, 179-183.

Tonka, T. \& Weiser, J. (2000) Iridovirus infection in mayfly larvae. Journal of Invertebrate Pathology, 76, 229-231.

Turlings, T.C.J., Loughrin, J.H., McCall, P.J., Rose, U.S.R., Lewis, W.J. \& Tumlinson, J.H. (1995) How caterpillar-damaged plants protect themselves by attracting parasitic wasps. Proceedings of the National Academy of Sciences of the United States of America, 92, 4169-4174.

Vasconcelos, S.D. (1996) Alternative routes for the horizontal transmission of a nucleopolyhedrovirus. Journal of Invertebrate Pathology, 68, 269-274.

Vera, M.L., Valverde, L., Popich, S.B. \& Ajmat de Toledo, Z.D. (1995) Evaluación preliminar de los enemigos naturales de Spodoptera frugiperda (J. E. Smith) (Lepidoptera: Noctuidae) en Tucumán, Argentina. Acta Entomológica Chilena, 19, 135-141.

Williams, T. (1993) Covert iridovirus infection of blackfly larvae. Proceedings of the Royal Society of London. Series B, 251, 225-230.

Williams, T. (1998) Invertebrate Iridescent Viruses. The Insect Viruses (ed. by L. K. Miller and L. A. Ball), pp. 31-68. Plenum, New York.

Williams, R.C. \& Smith, K.M. (1957) A crystallizable insect virus. Nature, 179, 119-120.

Wilson, K., Cotter, S.C., Reeson, A.F. \& Pell, J.K. (2001) Melanism and disease resistance in insects. Ecology Letters, 4, 637-649.

Accepted 6 July 2005 